\title{
軸流圧縮機のウインドミル駆動状態における動翼の仕事特性と損失の発生機構
}

\author{
藤澤 信道 ${ }^{* 1}$, 西山 直道 ${ }^{2}$, 太田 有 ${ }^{* 3}$, 後藤 尚志 ${ }^{* 4}$, 加藤 大 $^{* 5}$
}

\section{Rotor work characteristics and loss generation mechanism of an axial flow compressor at windmill operation}

\author{
Nobumichi FUJISAWA ${ }^{* 1}$, Naomichi NISHIYAMA ${ }^{* 2}$, Yutaka OHTA ${ }^{* 3}$, \\ Takashi GOTO*4 and Dai KATO* ${ }^{* 5}$

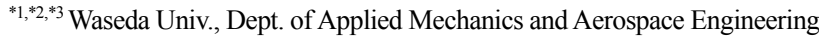 \\ 3-4-1 Okubo, Shinjuku-ku, Tokyo 169-8555, Japan \\ ${ }^{* 4,{ }^{*}}$ IHI Corporation, 3975-18 Haijima-Cho, Akishima-Shi, Tokyo 196-8686, Japan
}

Received: 11 December 2018; Revised: 25 February 2019; Accepted: 26 March 2019

\begin{abstract}
Work characteristics and loss generation mechanism of a single-stage axial flow compressor at windmill operation were investigated by experiment and CFD analyses. When the inlet flow coefficient is gradually increased from the design point, the rotor blade gradually enters the windmilling operation from the tip toward hub. The research attentions were focused on two windmilling operations, those were free-windmilling and highly loaded windmilling conditions. Total pressure loss under windmilling operations was mainly caused by three flow structures, those were (1) tip leakage flow from suction to pressure surface near the leading edge and that from pressure to suction surface near the trailing edge, (2) the interaction of separation vortices due to the highly negative incidence and the rotor leading-edge vortex, and (3) the boundary layer separation near the hub wall. The distribution of the rotor operating mode was found to exist not only in the span-wise direction but also in the chord-wise direction under the windmilling operations. The turbine mode region was observed near the leading edge, while the compressor mode region was observed near the trailing edge even in the highly loaded windmilling condition. Therefore, driving force of the windmilling was dominated not by the area of the turbine mode on the rotor blade but by the static pressure difference of suction and pressure surfaces on the rotor.
\end{abstract}

Keywords : Axial flow compressor, Windmill, Internal flow, Loss generation, CFD, DES

\section{1. 緒言}

航空エンジンが巡航中に失火すると，エンジンは流入空気のラム圧によって駆動されるウインドミル状態に陥 ることが知られている。高度の信頼性や安全性の向上が要求される航空エンジン設計においては，ウインドミル 状態で駆動されるファンや圧縮機の回転数を予測し，動静翼列内の非定常流れ場や翼に作用する非定常流体力， 損失の発生メカニズムなどを把握することは不可欠となっている．また近年では航空機の電動化に伴い，補助動 力装置 (APU) や各種ファンをウインドミル駆動させて電力供給を行うことも検討されており (Gill et al., 2010),

ウインドミル駆動時のファン，圧縮機特性を理解する重要性はますます増大している.

ウインドミル状態の内部流れ場に関しては，負の入射角に起因する大規模な剥離流れが動静翼列内に発生して 大きな全圧損失を引き起こすこと(Prasad and Load, 2010)や,ウインドミル駆動時の動翼ではシュラウドに近いチッ プ側でウインドミル駆動，ハブ側で圧縮機作動を示す傾向があり，そのスパン方向特性は翼の負荷特性に起因す

No.18-00493 [DOI:10.1299/transjsme.18-00493], J-STAGE Advance Publication date : 3 April, 2019

*1 正員, 早稲田大学 基幹理工学部 機械科学・航空学科（广169-8555 東京都新宿区大久保 3-4-1）

*2 早稲田大学大学院 基幹理工学研究科

*3 正員, フェロー，早稲田大学 基幹理工学部 機械科学・航空学科

*4 (株) IHI（广196-8686 東京都昭島市遅島町 3975-18）

*5 正員, (株) IHI

E-mail of corresponding author: yutaka@waseda.jp 
ること(Gunn and Hall, 2016)が明らかにされている．また Imaeda らは, 翼正圧面の大規模剥離に起因する全圧損失 は, 動翼よりもむしろ静翼において支配的であることを指摘し(Imaeda et al., 2011), その結果を受けて Goto らは, 静翼列内流れに着目した数值解析と翼間流れ場の実測結果を基に, 静翼列内を移流するスパン方向に軸を持つ非 定常縦渦の存在を示している(Goto et al., 2014).

一方，ウインドミル状態での動翼特性については，動翼仕事と駆動モードを評価するための指標として荷重係 数が定義され，ウインドミル駆動状態が 2 種類に分類されている(Binder et al., 2015), (Ortolan et al., 2017). 1 つは 動翼と流体間でエネルギーの授受が相殺され荷重係数が零となる Free-Windmilling 状態（以下，FW 状態と略記） で，動翼はいわゆる空回り状態となっている．もう一つは荷重係数が負となり動翼がタービンとして駆動してい る状態であり, Highly Loaded Windmilling 状態（以下，HL 状態と略記）あるいはLoad-Controlled Windmilling 状態 と呼ばれている，さらに近年になって Hirayama らは，FW 状態と HL 状態にある動翼において，スパン方向のみ ならずコード方にも作動状態に違いが現れることを示している(Hirayama et al., 2017). また, HL 状態の動翼特 性や非定常内部流れ場に関する詳細な調査検討も実施されている(Ortolan et al., 2018).

これらの先行研究によって, ウインドミル駆動時の動翼仕事特性や内部流れ場の把握は近年著しく進んできて いるが, 動静翼列内の大規模剥離に伴う非定常流れ構造の把握や損失の発生機構, ウインドミル状態の動翼列か ら取り出せる仕事量の評価, 静翼列内での詳細な流れ状況など, 未だに不明な点は数多く残されている. そこで 本研究では, 航空エンジン用軸流圧縮機の前段を模擬した単段軸流圧縮機試験装置を用いて, 動翼の仕事特性と 内部流れ場の把握, 更には大規模剥離流れに伴う損失の発生機構についての知見を得るために詳細な実験計測と 数值解析を実施した. 特に, FW 状態と HL 状態にある動翼の仕事特性と内部流れ場に研究の焦点を当て, ウイ ンドミル駆動がスパン方向の特性のみならずコード方向特性によって強く支配されることや，動翼表面上のター ビン駆動領域が流量係数によって余り大きな影響を受けないこと, 更には動翼列内での損失の発生機構がウイン ドミル状態と内部流れ場によって大きく変化することを明らかにした.

\section{2. 主な記号と定義}

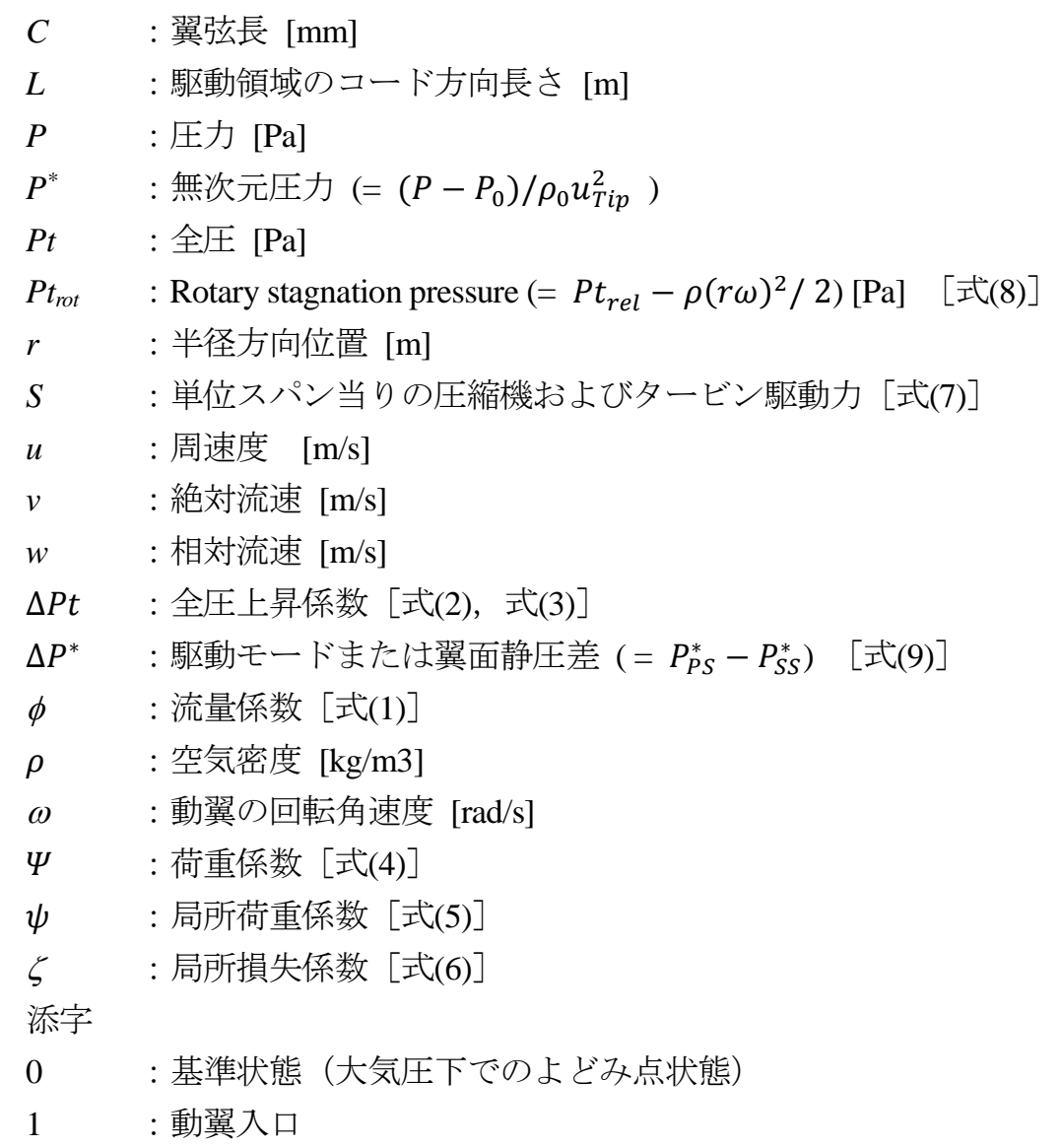




$\begin{array}{ll}2 & : \text { 動翼出口（静翼入口） } \\ 3 & : \text { 静翼出口 } \\ \mathrm{rel} & : \text { 相対系 } \\ \mathrm{X} & : \text { 軸方向 } \\ \theta & : \text { 周方向 } \\ \mathrm{C} & : \text { 圧縮機 } \\ \mathrm{T} & : \text { タービン } \\ \mathrm{RB} & : \text { 動翼 } \\ \mathrm{SV} & : \text { 静翼 } \\ \mathrm{Hub} & : \text { 動翼付根 } \\ \mathrm{Tip} & : \text { 動翼先端 } \\ \mathrm{PS} & : \text { 翼正圧面 } \\ \mathrm{SS} & : \text { 翼負圧面 } \\ \text { 略語 } & \end{array}$

FW : Free-Windmilling 状態

HL : Highly Loaded Windmilling 状態

\section{3. 実験装置および実験方法}

\section{$3 \cdot 1$ 実験装置}

供試圧縮機は航空エンジン用多段軸流圧縮機の最前段を模擬した動静翼列を円形風洞内に設置した単段軸流圧 縮機であり, $5.5 \mathrm{~kW}$ の三相誘導電動機により駆動される. 供試圧縮機の概略図を図 1 に, 設計仕様を表 1 に示す. 動翼枚数は 24 枚，静翼枚数は 36 枚であり，動静翼はそれぞれ $0.65 \mathrm{~mm}, 0.45 \mathrm{~mm}$ の翼端隙間を有している。風洞 出口には $25 \mathrm{~kW}$ の三相誘導電動機によって駆動される遠心送風機が設置されており，その流量を調整することで 風洞内流入流量と圧縮機回転数を独立に設定することができる．本研究では，航空エンジンが上空で失火した際 に設計值の約 $12 \%$ ま゙エンジン回転数を回復させることができれば，ウインドミルスタートが可能であるという 従来の報告(Walsh and Fletcher, 2004)に基づき，圧縮機回転数を設計值の約 $12 \%$ に相当する $900 \mathrm{~min}^{-1}$ に固定し，遠 心送風機を用いて流入流量を増加させることでウインドミル状態を実現している.

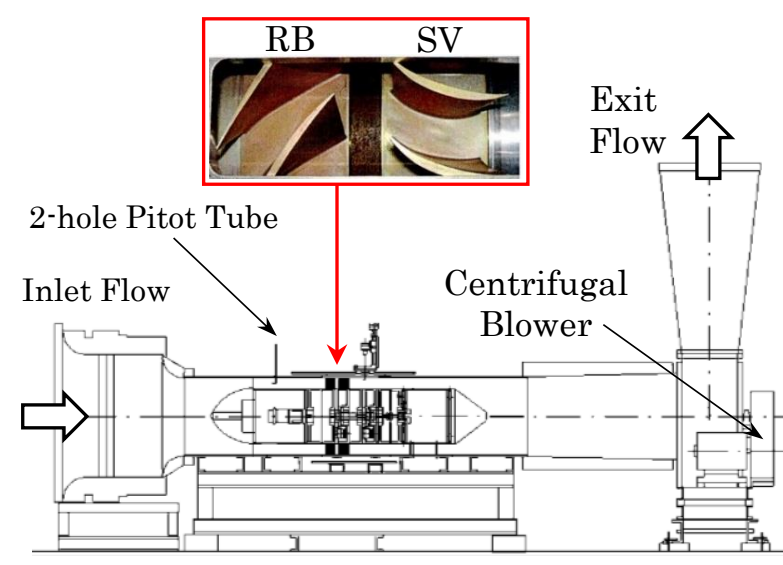

Fig. 1 Overview of tested single-stage axial-flow compressor used for windmill experiments. Volume flow rate was measured by 2-hole Pitot tube installed upstream of RB. Windmilling operations were realized by auxiliary blower at the outlet duct end.
Table 1 Design performance of tested axial-flow compressor and dimensions of RB and SV. Experiments were carried out at $900 \mathrm{~min}^{-1}$, about $12 \%$ of design speed.

\begin{tabular}{|ll|c|}
\hline $\begin{array}{l}\text { Rotating Speed } \\
\text { (Design, EXP) }\end{array}$ min $^{-1}$ & 7680,900 \\
\hline \multicolumn{2}{|l|}{ Number of Rotor Blades } & 24 \\
\hline \multicolumn{2}{|l|}{ Number of Stator Vanes } & 36 \\
\hline Radius (Casing, Hub) m $\quad \mathrm{kg} / \mathrm{s}$ & $\begin{array}{c}0.2458 \\
0.1775\end{array}$ \\
\hline Mass Flow Rate & 10.14 \\
\hline Pressure Ratio & $\mathrm{mm}$ & $0.65,0.45$ \\
\hline Tip Clearance (RB, SV) & 0.574 \\
\hline Blade Tip Mach Number & \\
\hline
\end{tabular}




\section{$3 \cdot 2$ 実験方法}

円形風洞内への流入流量は風洞入口部に設置された 2 孔ピトー管を用いて測定した，入口の乱れ強さは，風洞 入口部に熱線流速計を設置した計側によると約 $4 \%$ ある. また図 2(a)に示すように, 動翼前縁から $1.034 C_{R B}$ 上 流の動翼入口部（測定点(1)，動翼後縁から $0.195 C_{R B}$ 下流の動翼出口部（測定点(2)）および静翼後縁から $1.313 C_{S V}$ 下流の静翼出口部（測定点(3)）における全圧，周方向流速を 5 孔ピトー管により測定した. さらに，測定点(2)お よび(3)では単一 I 型熱薄膜プローブ(DANTEC 社製 55R01)を翼スパン方向にトラバースすることで翼間流れのス パン方向特性を測定した. 熱薄膜プローブからの出力は DANTEC 社製 Streamline システムのブリッジ回路を経 た後, A/D 変換ボードを介してコンピュータに記録した. これらの計測結果より圧縮機性能を調査すると共に, Euler の理論から動静翼列の負荷特性を求めた.

動翼表面上圧力は薄型圧力センサー（Kulite 社製 LQ062-25SG）を図 2(b)に示すように，動翼正圧面および負圧 面上のスパン方向 3 箇所 (Tip から $10 \%, 50 \%, 90 \%)$, コード方向 9 個所 $\left(0.1 C_{R B}\right.$ から $0.9 C_{R B}$ まで $0.1 C_{R B}$ 毎）の 総計 54 箇所に順次貼付して非定常計測を実施した. 薄型圧力センサーからの測定電圧は動翼内部に設置された テレメータ送信機（datatel 社製 dt1001T-ST）から外部の受信機（datatel 社製 dt1001R2-S） 八無線送信され，動翼 回転と同期した計測を実施した。 サンプリング周波数は $10 \mathrm{kHz}$ ，サンプリング点数 8192 点とし，動翼からのトリ ガー信号に同期させて 128 回のアンサンブル平均を実施したが，本報告ではそれらの時間平均值を用いて動翼駆 動モードの分析を行っている.

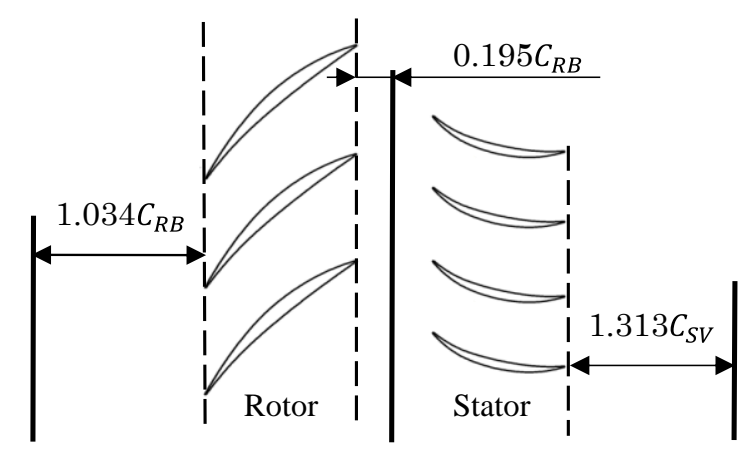

(1) (2)

5-hole Pitot Tube 5-hole Pitot Tube Hot Wire Probe 5-hole Pitot Tube Hot Wire Probe

(a) Measuring locations of RB and SV performances.

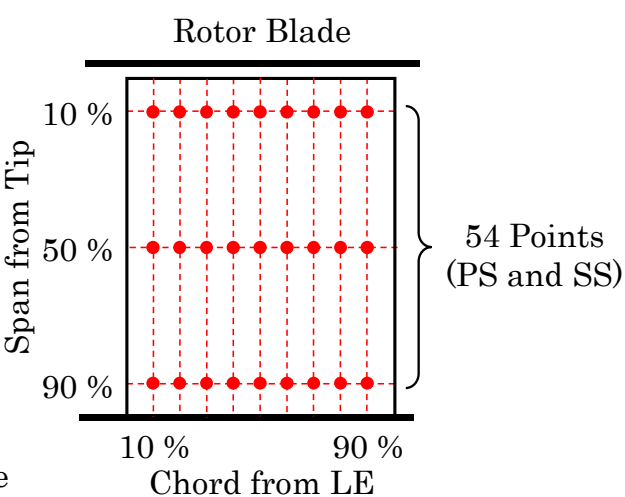

(b) Measuring points of rotor blade surface pressure.

Fig. 2 Rotor blade and stator vane performances were measured by 5-hole Pitot tubes and hot wire anemometers at 3 locations, ahead of RB (1), behind RB (2) and behind SV (3). Also, rotor performance was evaluated by surface pressure measured at 54 points on the rotor surface.

\section{4. 数值計算手法}

\section{$4 \cdot 1$ 解析スキーム}

ウインドミル状態における流れ場の傾向と動静翼列内流れの詳細な構造を調査・把握するために, URANS (Unsteady Reynolds Averaged Navier-Stokes) 解析と DES（Detached Eddy Simulation）解析を実施した. 支配方程式 は連続方程式，3次元圧縮性 Navier-Stokes 方程式，エネルギー保存の式および理想気体の状態方程式であり，有 限体積法により離散化した。対流項には MUSCL 法 (van Leer, 1979)により空間 3 次精度とした Roe Scheme (Roe, 1980)を用い，粘性項は中心差分的に評価した．また，時間積分にはMFGS 陰解法(Shima, 1997)を採用した. 乱流 モデルには URANS でSST k- $\omega$ (Menter, 1994), DES には Strelets らが提案した SST k- $\omega$ ベースの SST-DES (Strelets, 2001）を使用した。この DES 解析では，局所的な乱流の渦スケールと格子幅の大小関係に応じて非定常的に URANS/LES 領域を自動的に切り替えることが可能である. 本研究において, 解析領域全体で壁面付近は URANS, 主流部は LES 領域として良好に URANS/LES 領域の切り替わりが実行されていることを確認済みである 
(Hirayama et al., 2017). 動翼回転数は実験と同じ $900 \mathrm{~min}^{-1}$ とし, 相対系には慣性力として遠心力およびコリオリカ を考慮した。

\section{$4 \cdot 2$ 解析格子と境界条件}

解析格子の概略図を図 3(a)に示す. 解析領域として全周の 1/12 に相当する動翼 2 翼間，静翼 3 翼間を対象とし た部分流路解析を実施した. URANS とDES では異なる格子点数の格子を用いており, 総格子点数はURANS で 約 800 万点，DES では約 2550 万点である. 最小格子幅は使用した乱流モデルに適した值を設定しているが，い ずれの計算においても $y^{+}<1$ の条件を満足している. 設計運転状態 $(\phi=0.5)$ における平均 $y^{+}$值は URANS で 0.60 , DES では 0.30，HL 状態（ $\phi=1.2 ）$ においてはURANS で 1.43, DES では 0.67 となっている，また，細かな渦構 造の調查を目的として設計状態 $(\phi=0.5)$, FW 状態 $(\phi=0.9)$ および HL 状態 $(\phi=1.2)$ に対して実施した DES

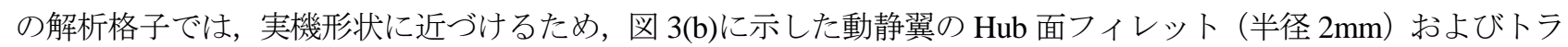
バース計測用の静翼 Tip クリアランスも模擬している. ただし，動静翼間流路のスパン方向の格子点数が 132 点 であるのに対し，動翼および静翼のクリアランス部の格子点数はスパン方向にそれぞれ， $51 ， 35$ 点である.

動翼前縁から $1.3 C_{R B}$ 上流側に配置された入口での境界条件として全温および全圧を固定した．また，入口での 主流の乱れ強さは，実験と同じ 4\%に設定した。出口側には圧力波の減衰を目的とした Buffer 領域を設け，静翼 後縁から 6.7 $C_{S V}$ 下流の出口境界条件としては質量流量を固定して，1 次元無反射境界を設定した。相対系と絶対 系の境界にはスライディング格子を設け，周方向には周期境界を適用した。壁面境界には流速に粘着条件を，密 度，圧力にはノイマン条件を課した。

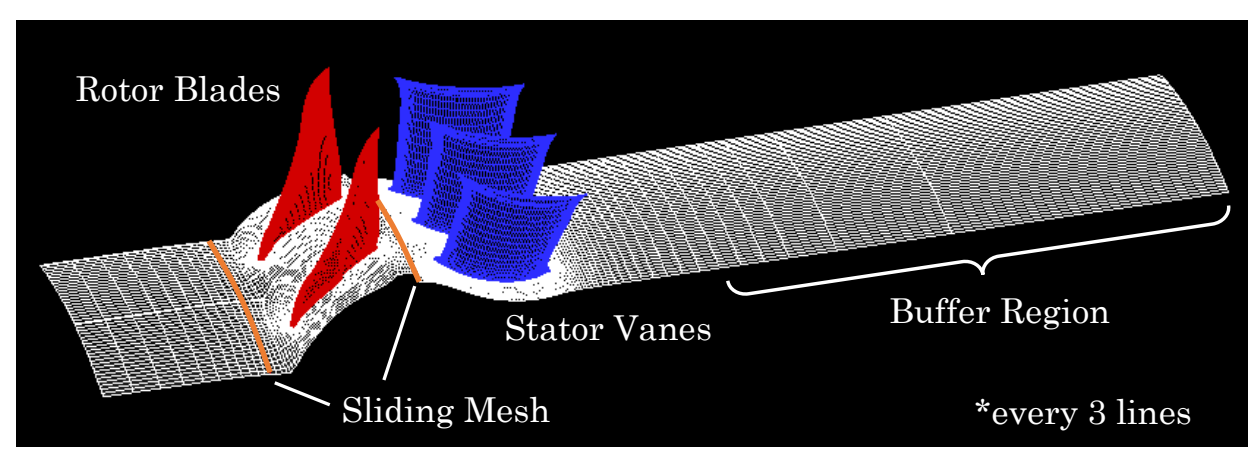

(a) Overview of numerical domain.
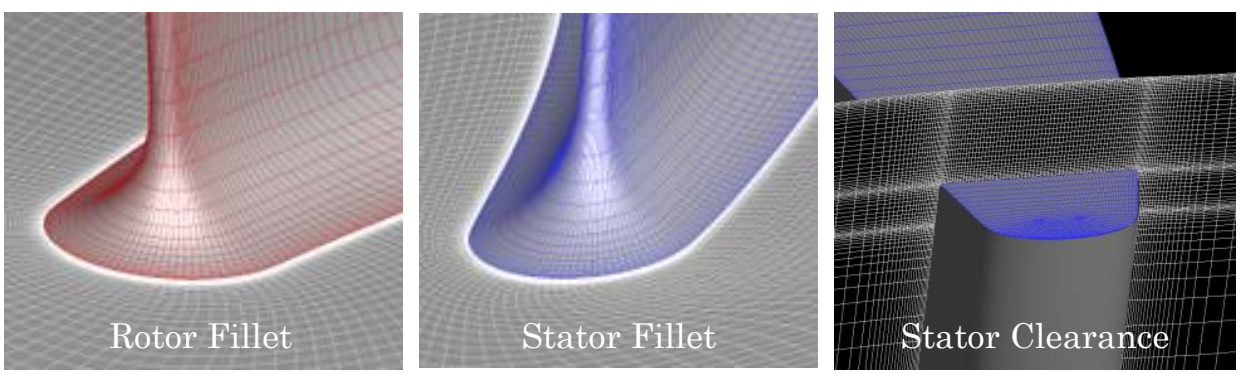

(b) Close up of rotor and stator fillets, and tip clearance of stator vane.

Fig. 3 Numerical domain was composed of $2 \mathrm{RB}$ and $3 \mathrm{SV}$ passages. Inlet boundary was located at $1.3 C_{R B}$ ahead of rotor leading edge and outlet boundary was $6.7 C_{S V}$ behind the stator trailing edge. Fillets and tip clearances of both RB and SV were considered.

\section{5. 圧縮機性能と翼列特性}

\section{5・1 ウインドミル状態の動静翼列の特性と駆動形態}

圧縮機の運転回転数を一定に保ったまま，設計状態から質量流量を順次増加させると，負の入射角の増大に伴 い動翼正圧面側での剥離が顕著になり，圧力上昇と動力は徐々に低下して，圧縮機効率も劣化する大流量側での 非設計運転状態となる，さらに質量流量を増加させると，圧縮機は流体にエネルギーを与える圧縮機作動状態か 


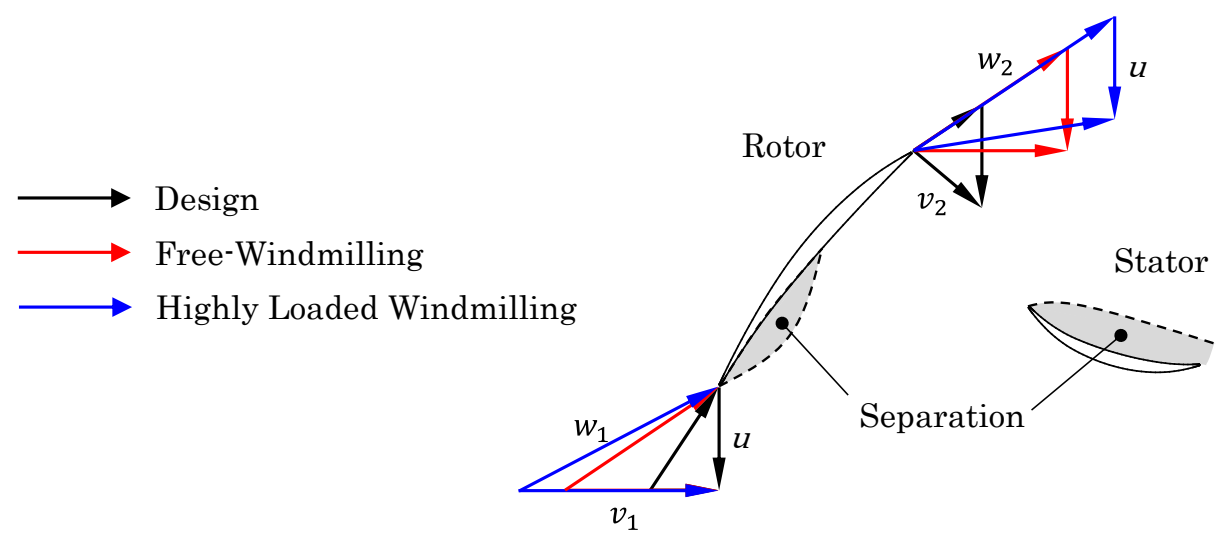

Fig. 4 Rotor velocity triangles at design (black), free-windmilling (red), and highly loaded windmilling (blue) conditions. According to Euler's theory, circumferential component of absolute velocity at rotor exit is zero at free-windmilling condition, and it shows negative value at highly loaded windmilling condition. Large separation regions were generated on pressure surfaces of both RB and SV because of the highly negative incidence to the rotor.

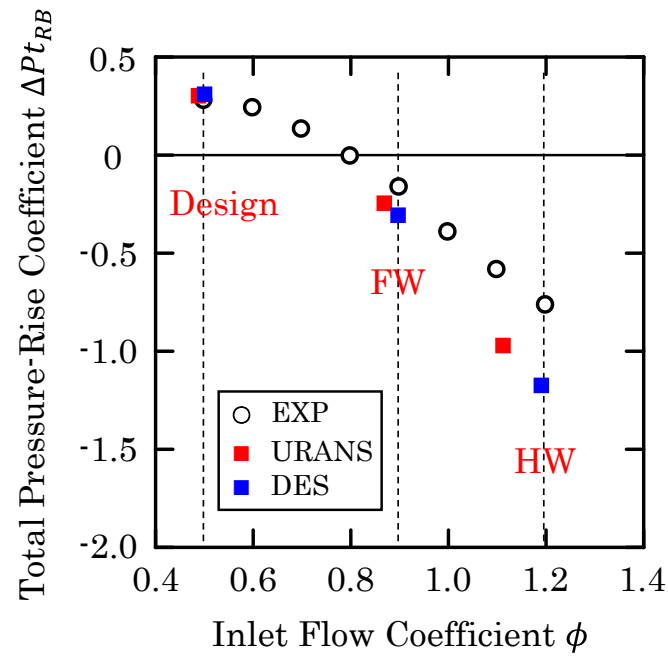

(a) Rotor blade

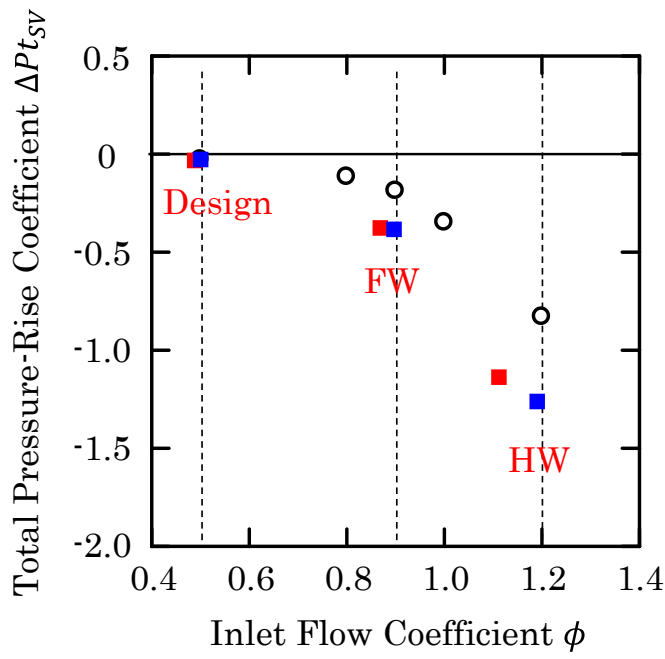

(b) Stator vane

Fig. 5 Total pressure-rise characteristics of rotor blade and stator vane at windmilling conditions. Total pressure-rise coefficient of rotor blade becomes almost zero at $\phi=0.8$, and remarkable total pressure loss was generated within stator vanes.

ら，流体からエネルギーを受け取ってタービン駆動され，動力を発生する状態へと変化する．この状態がウイン ドミル状態である，ウインドミル状態での動静翼列内流れ場は，図４に示した速度三角形のように，負の入射角 が増大して動静翼の正圧面側に大規模な剥離流れを形成することが知られている．動翼と流体間のエネルギー授 受がちょうど相殺されて動翼が空回りする状態が FW 状態であり, Euler の理論から動翼下流側での絶対流速の 周方向速度成分は $v_{\theta 2}=0$ となる. さらに質量流量を増大させた HL 状態では絶対流れ角が負となり, 周方向速度 成分も $v_{\theta 2}<0$ となって動力が発生するが，正圧面側の大剥離によって大きな損失が発生する(Prasad and Load, 2010).

供試圧縮機の動翼および静翼の性能試験結果を図 5, 動翼の荷重係数と流量係数の関係を図 6 に示寸.ここで, 流量係数，全圧上昇係数，荷重係数はそれぞれ以下のように定義される.

流量係数 : $\quad \phi=v_{x} / u_{\text {Tip }}$

全圧上昇係数（動翼）: $\Delta P t_{R B}=\left(P t_{2}-P t_{1}\right) / \rho_{0} u_{T i p}^{2}$ 
全圧上昇係数 (静翼) : $\Delta P t_{S V}=\left(P t_{3}-P t_{2}\right) / \rho_{0} u_{T i p}^{2}$

荷重係数： $\quad \Psi=\int_{r_{H u b}}^{r_{T i p}} \rho u\left(V_{\theta 2}-V_{\theta 1}\right) \mathrm{d} r / \rho_{0} u_{T i p}^{2}$

図より URANS およびDES による数值計算結果は, 実験結果（図中 EXP で表示）と比べてやや損失を過大評 価しているが, 定性的傾向は概ね良好に一致している. 供試圧縮機の設計点は $\phi=0.5$ であり, 全圧上昇係数 $\Delta P t_{R B}$ および荷重係数 $\Psi$ の結果から動翼は圧縮機作動を示していることが確認できる. また， $\phi=0.8$ 付近で $\Delta P t_{R B}=0$ と なるが，実際に荷重係数が $\Psi=0$ となる $\mathrm{FW}$ 状態は $\phi=0.9$ である. $\phi>0.9$ の範囲では動翼がタービンとして動力 を発生する HL 状態となっている. 静翼の全圧上昇係数 $\Delta P t_{S V}$ は設計点 $\phi=0.5$ ではほぼ零であり, 流量の増大と共 に急激に減少して剥離流れによる大規模な損失が発生することを示している. 本研究では設計点である $\phi=0.5$, $\mathrm{FW}$ 状態となる $\phi=0.9$ に加えて, HL 状態の代表例として $\phi=1.2$ の場合を取り上げ，これら 3 種類の運転状態での 動翼列特性の検討を行った.

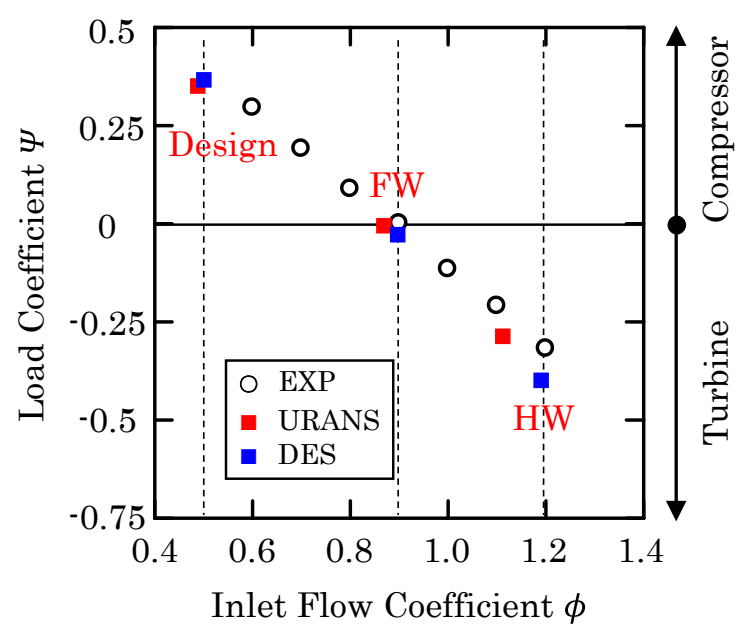

Fig. 6 Load coefficient and operating mode of rotor at windmilling conditions. The operating mode changes from compressor to turbine at $\phi=0.9$, which was called free-windmilling condition. When $\phi>0.9$, the compressor operates like a turbine and the rotor was driven by ram pressure of the incoming flow. These states were called highly loaded windmilling conditions.

\section{$5 \cdot 2$ 動翼のウインドミル特性}

動翼スパン方向の局所性能を記述するパラメータとして局所荷重係数 $\psi(r)$ と局所損失係数 $(r)$ をそれぞれ次 式のように定義した.

$$
\begin{aligned}
& \psi(r)=\rho u\left(v_{\theta 2}-v_{\theta 1}\right) / \rho_{0} u_{T i p}^{2} \\
& \zeta(r)=\left\{\left(P t_{2}-P t_{1}\right)-\rho u\left(v_{\theta 2}-v_{\theta 1}\right)\right\} / \rho_{0} u_{T i p}^{2}
\end{aligned}
$$

局所荷重係数 $\psi(r)$ と局所損失係数 $\zeta(r)$ の動翼スパン方向分布をそれぞれ図 7, 図 8 に示寸.

図 7 より設計点 $(\phi=0.5)$ では全スパンにわたって圧縮機作動, HL 状態 $(\phi=1.2)$ では全スパンでタービン駆 動であり, 実験と数值計算結果の定性的な傾向は概ね一致している. 一方, FW 状態 $(\phi=0.9)$ では先行報告にも あるように(Gunn and Hall, 2016)，Hub 側では圧縮機作動，Tip 側ではタービン駆動を示寸傾向にあり，2つの駆動 モードがスパン方向に共存しているように見える. 実験と数值計算結果にもその定性的傾向に違いが認められる が, その原因は後に図 10, 図 15 に示寸ように, 本試験装置の動翼では駆動モードの切り替わりがスパン方向で はなく, 主にコード方向に強く支配されるためであると考えられる. 一方, 図 8 に示した局所損失係数の分布よ り, 設計点 $(\phi=0.5)$ では翼端漏れ流れに起因すると考えられる損失が Tip 側に発生している. FW 状態と HL 状 


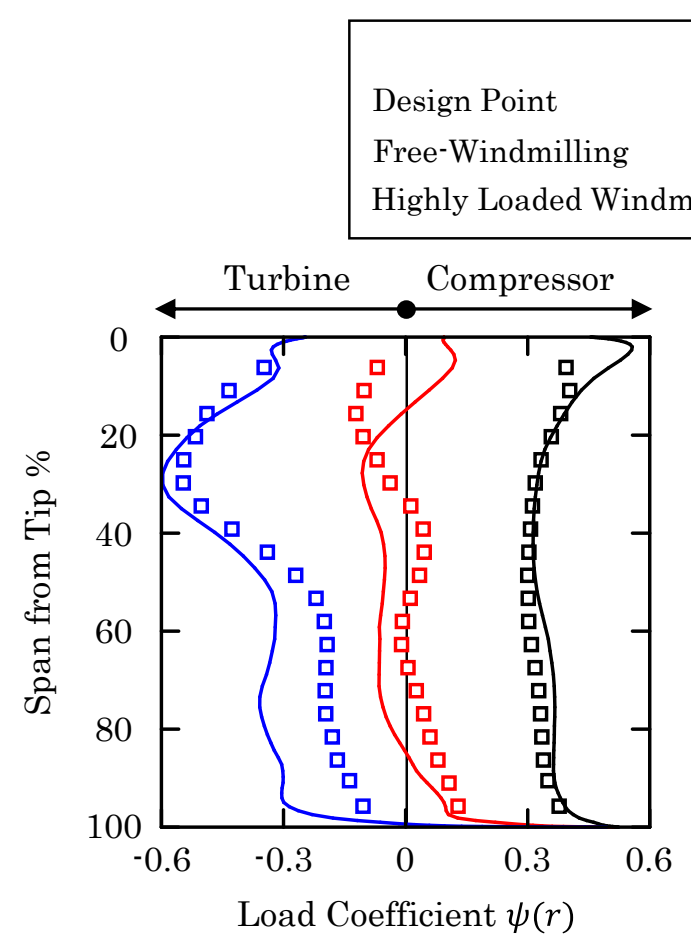

Fig. 7 Span-wise distribution of local load coefficient $\psi(\mathrm{r})$ at design, free-windmilling and highly loaded windmilling conditions. At design point, rotor blades were driven like a compressor in all span, while at highly loaded windmilling condition, rotor blades were driven like a turbine in all span. In case of free-windmilling condition, driving mode was changed in span-wise direction.

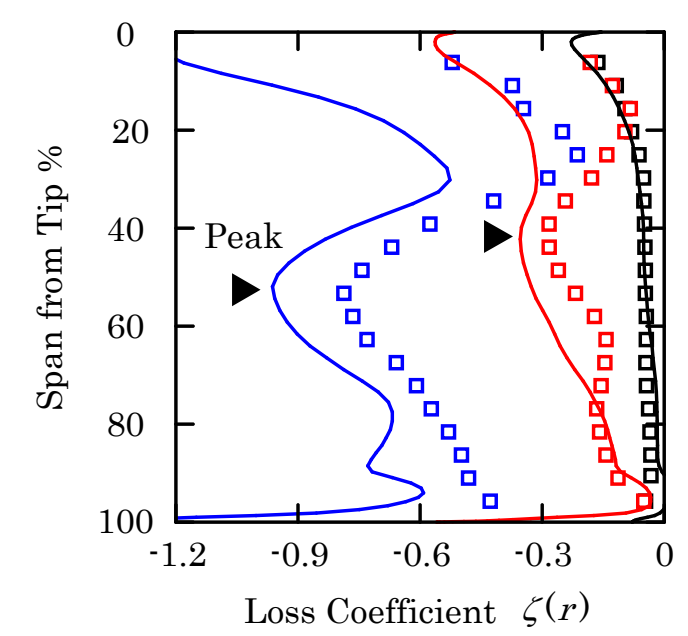

Fig. 8 Span-wise distribution of local loss coefficient $\zeta(r)$ at design, free-windmilling and highly loaded windmilling conditions. In the windmilling operation, loss was mainly generated at three regions, those were tip clearance, hub wall and mid span areas. The most dominant loss was generated in the mid span shown by black triangles in the figure.

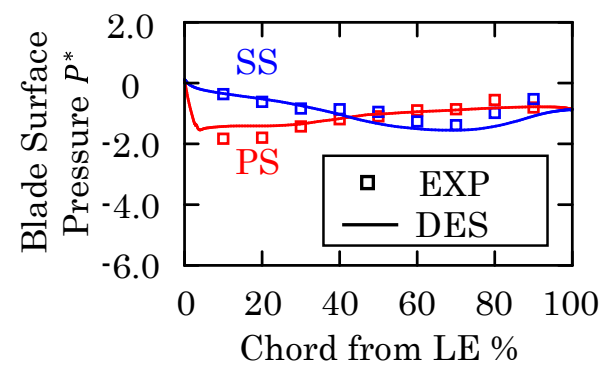

(a) Free-windmilling $(\phi=0.9)$

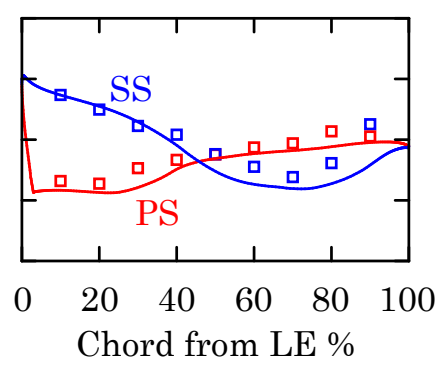

(b) Highly loaded windmilling $(\phi=1.2)$

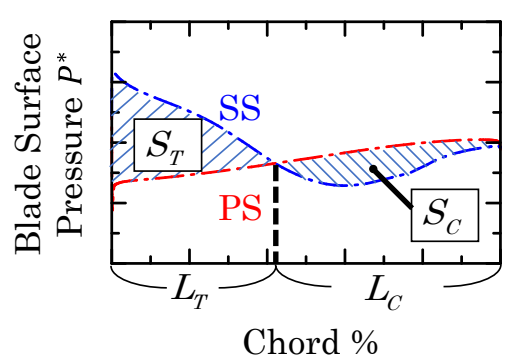

(c) Parameters to evaluate the operating mode.

Fig. 9 Chord-wise distribution of rotor surface pressure at free-windmilling and highly loaded windmilling conditions (10\% span from tip). Static pressure on the suction side was larger than that on the pressure side near the leading edge, and was opposite near the trailing edge. The length of the turbine operation mode LT was increased with the flow coefficient. The operating mode was found to change not only in the span-wise direction but also in the chord-wise direction.

態では，数值計算結果は実験結果と比べて損失を過大に評価する傾向が認められるが，定性的なスパン方向の分 布特性は概ね一致している. Tip 側の漏れ流れに加えて, Hub 面近傍とミッドスパン部にも図中にムで示した損 失の大きい領域が存在している。このスパン方向位置は, FW 状態では Tip から約 40\%スパン, HL 状態では Tip から約 50\%スパンに相当する. これらの領域では局所荷重係数 $\psi(r)$ も増加する傾向を示しており, 損失の発生が 仕事特性にも影響を与えていることを示唆している.

さらに, 動翼のコード方向特性を調査するために行った動翼表面上圧力の測定結果と数值計算結果を無次元化 して図 9(a)，(b)に示寸．ここでは FW 状態と HL 状態の一例として，Tip から 10\%スパン位置での結果を示した が, 他のスパン位置での結果も定性的には同じ傾向を示す.測定結果と数值計算結果は概ね良好に一致し, 翼前 
縁近傍では負圧面側圧力が正圧面側圧力よりも大きくなるタービン駆動状態，後縁近くでは圧縮機作動状態にな っていることがわかる．ここで動翼のコード方向特性を定量的に評価するためのパラメータとして，図 9(c)に示 した駆動領域のコード方向長さ $L$ と, 単位スパン当りの翼負荷つまり各駆動モードの強さを表す駆動力 $S$ を用い る. なお，単位スパン当りの駆動力 $S$ は次式で定義する.

$$
\begin{aligned}
& S_{\text {mode }}=\int_{L_{\text {mode }}}\left(P_{P S}^{*}-P_{S S}^{*}\right) \mathrm{d} L \\
& \operatorname{mode}=T: \text { タービン }, \quad C: \text { 圧縮機 } \\
& P^{*}=\left(P-P_{0}\right) / \rho_{0} u_{T i p}^{2}: \text { 無次元動翼表面上圧力 }
\end{aligned}
$$

タービン駆動力 $S_{T}$ および圧縮機駆動力 $S_{C}$ は, それぞれ図中の斜線部面積に相当し, タービン駆動では負の值 を，圧縮機作動している場合には正の值を示す。

スパン方向 3 断面（Tip から 10\%，50\%，90\%）におけるタービン駆動領域のコード方向長さ $L_{T}$ と，単位スパ ン当りの駆動力 $S$ の変化をそれぞれ図 10 , 図 11 に示寸.

タービン駆動領域の長さ $L_{T}$ は流量係数の増加と共に単調に増大寸る傾向を示寸．設計点（ $\phi=0.5 ）$ では全ての スパンで $L_{T}$ はほぼ零であり動翼の圧縮機作動が確認できる．しかし，最も $L_{T}$ の増大が顕著な Tip から $10 \%$ スパ


Inlet Flow Coefficient $\phi$
(a) $10 \%$ Span from Tip
(b) $50 \%$ Span from Tip
(c) $90 \%$ Span from Tip

Fig. 10 Length of turbine operation mode $L_{T}$ on the rotor surface obtained by surface pressure measurements and CFDs. Turbine mode was located almost $50 \%$ chord from the rotor leading edge even in the highly loaded windmilling operation. Therefore, driving force of the windmilling condition was determined not by the area of the turbine mode but by the strength of the turbine mode, i.e. pressure difference of both sides of rotor blade.

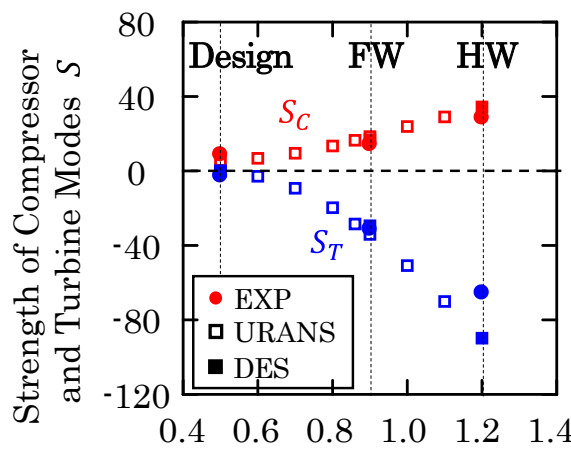

(a) $10 \%$ Span from Tip
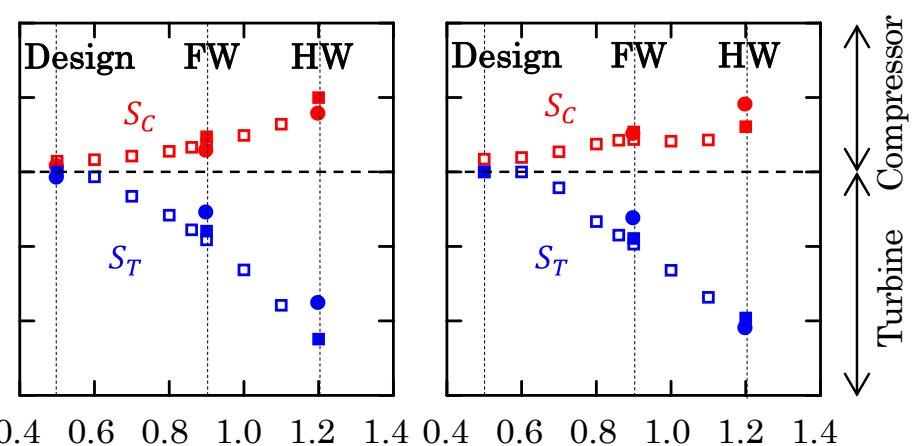

Inlet Flow Coefficient $\phi$

(b) $50 \%$ Span from Tip

(c) $90 \%$ Span from Tip

Fig. 11 Strength of compressor and turbine modes, i.e. static pressure difference between pressure and suction surfaces, on the rotor obtained by surface pressure measurements and CFDs. Strength of turbine mode increased remarkably with the inlet flow coefficient and dominated the windmilling characteristics. 
ン位置においても，流量係数が $\phi=0.9$ 近くで $L_{T}$ は一定值に漸近し，FW 状態や HL 状態でも動翼コード方向の下 流側半分では圧縮機作動が継続されていることがわかる. Tip から 90\%スパン位置（Hub 側）では $\phi=1.2$ までの 範囲で $L_{T}$ は単調に増大寸るが，タービン駆動を示寸のはたかだか前縁から $0.3 C_{R B}$ までの限られた範囲である.

一方，図 11 によると動翼正圧面と負圧面との圧力差で定義される駆動力 $S$ も流量係数の増加と共に単調に増 大寸るが，圧縮機駆動力 $S_{C}$ に比べてタービン駆動力 $S_{T}$ の変化は顕著である. また，圧縮機駆動力 $S_{C}$ の変化は動 翼スパン方向でほとんど変化しないが，タービン駆動力 $S_{T}$ は Tip 側でより変化が大きく, 動翼は Tip 側から順次 タービン駆動へと移行していくことがわかる. しかし, 図 10 の結果と合わせて考えると, FW 状態および HL 状 態の動翼では, タービン駆動となる動翼面上の範囲は流量係数によってあまり変化せず，駆動力つまり動翼両面 の圧力差のみが増大していることがわかる.

\section{6. ウインドミル状態における内部流れ}

\section{$6 \cdot 1$ 動翼の流れ構造と損失の発生機構}

動翼ミッドスパン断面における相対速度コンターを図 12 に示寸. 図中の白線は軸流速度 $v_{x}=0$ の等值線であ り，翼近傍の逆流領域を可視化することができる．設計点（ $\phi=0.5 ）$ では，流れが入射角ほぼ零で動翼に流入し ており，逆流領域は負圧面後縁近傍のみにわずかに確認される，一方，ウインドミル状態では，負の入射角に起 因する剥離と再付着が正圧面側で発生し，前縁近傍には逆流域も存在している. 正圧面側の大剥離の影響により 翼間流路の有効面積が減少し，負圧面側の流れが加速されていることがわかる．HL 状態 $(\phi=1.2)$ では FW 状態 $(\phi=0.9)$ と比較して, 正圧面側の再付着点が下流側に移動して剥離泡が拡大寸ると共に, 負圧面側の加速流れ も一層顕著になっている.

動翼下流側測定点(2における損失分布を図 13 に示寸. 損失の評価には, ターボ機械において動翼や羽根車など 回転系の損失評価指標として多用されている Rotary stagnation pressure $P t_{r o t}$ (Greitzer et al., 2004)を用いたＰ $P t_{r o t}$ は 相対全圧から動翼の回転によって発生する正味の動圧を差し引いた值であり，次式で定義される.

$$
P t_{\text {rot }}=P t_{r e l}-\rho(r \omega)^{2} / 2
$$

図 13 にはP $t_{r o t}$ を無次元表示した.
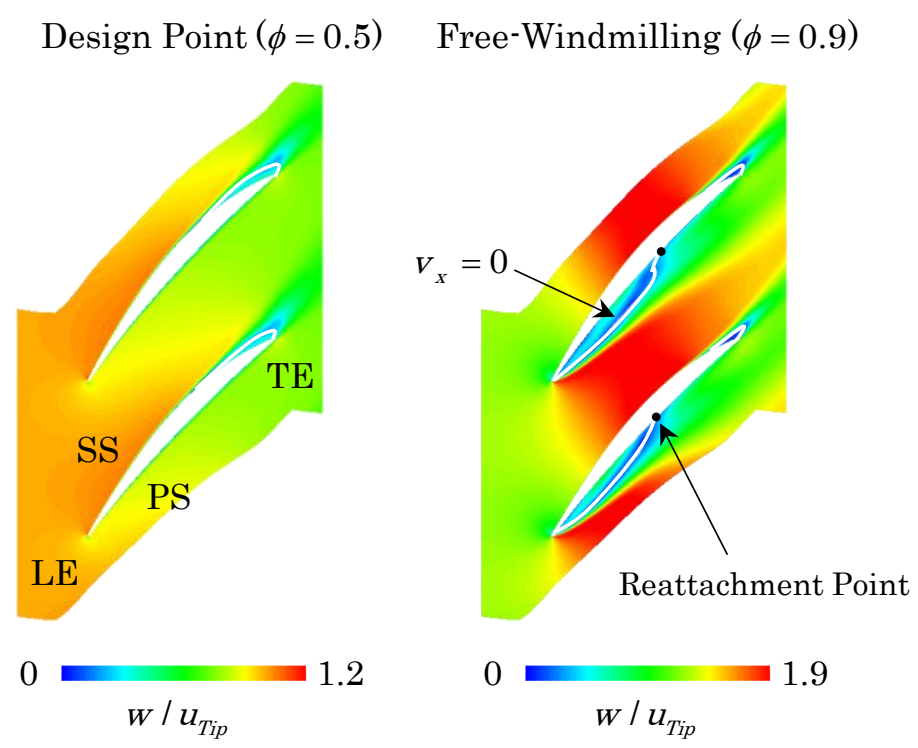

Highly Loaded Windmilling

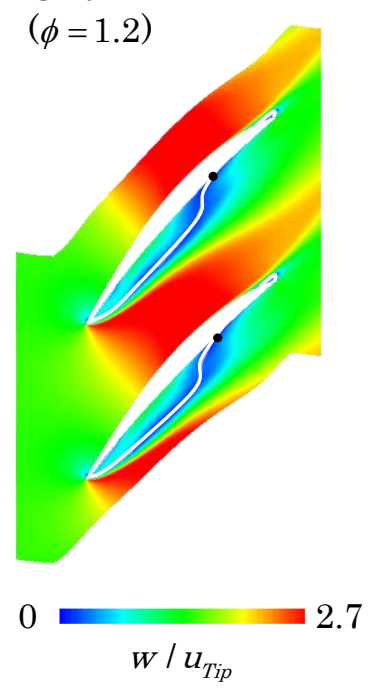

Fig. 12 Blade-to-blade contours of relative velocity at mid-span (50\% span from tip) obtained by DES. A large leadingedge separation, reattachment and reverse flow regions were recognized on the pressure surface. Main flow on the rotor suction surface was accelerated by the large separation on the pressure side. 
Design Point $(\phi=0.5) \quad$ Free-Windmilling $(\phi=0.9) \quad$ Highly Loaded Windmilling

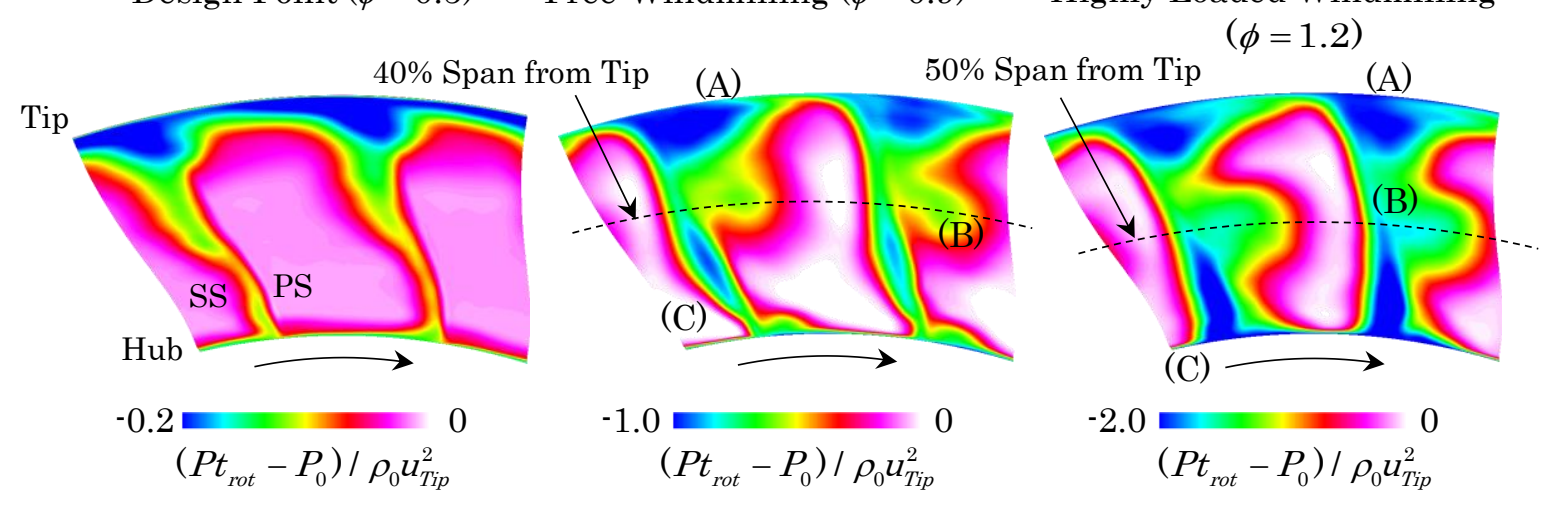

Fig. 13 Distribution of rotary stagnation pressure at rotor exit under design, free-windmilling and highly loaded windmilling conditions obtained by DES. Total pressure loss was mainly generated at tip region (A), mid-span (B) and hub region (C). Location of the mid-span loss core (B) depends on the windmilling conditions, and moved toward the mid-span with the flow coefficient.

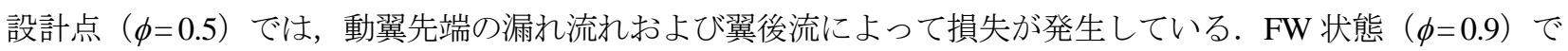
は図中(A)で示した翼端部の損失領域がより拡大寸ると共に, 正圧面側の Tip から約 40\%スパン位置に顕著な損失 領域(B)が発生している. 一方, HL 状態（ $\phi=1.2 ） て ゙ は$ 図中(B)に示した顕著な損失領域が Tip から 50\%スパン位 置まで移動すると共に, Hub 側にも損失領域(C)が発生している.この傾向は図 8 に示した局所損失係数 $\zeta(r)$ の パン方向分布にも数值計算結果として顕著に現れており, Hub 面近傍において数值計算結果が損失を過大評価し ている要因になっている.

ウインドミル状態における動翼での損失発生機構を調査するために, critical point 法 (Sawada, 1995)を用いて渦 芯を可視化し, 無次元へリシティによって色付けした渦と, 図 13 に示した Rotary stagnation pressure $P t_{\text {rot }}$ の結果 を併記して図 14 に示寸. 図 14 の右側には翼端部の流線を示した. 図中には動翼前縁からの流線（白線, 黒線), 先端隙間内の流線（赤線, 青線), 八ブ面からの流線（黄線）も併記した.

図 14(a)より, FW 状態（ $\phi=0.9 ）$ では負の入射角に起因して正圧面前縁近傍に大きな剥離渦が生成され，その 渦芯は八ブ面近傍からスパン方向に巻き上げられて翼端部まで達し, 図 13 に示した損失領域(A)を形成している. その様子は前縁部からの黒色の流線が集積してスパン方向に巻き上がり損失領域(A)を形成していることからも 理解できる，一方，正圧面前縁先端部には前縁渦（図中 LEV）(後藤他, 2010), (藤澤他, 2015)が生じており，スパ ン中央部においてスパン方に軸を持つ縦渦と干渉することで渦崩壊を起こし，大きな損失領域を翼スパン中央 部に生成する．よって，この近傍を通過する流線（図中白色の流線）によって損失領域(B)が Tip から約 40\%スパ ン位置に形成されることになる. 翼端部の流線に着目寸ると, 前縁近傍では負圧面から正圧面への漏れ流れ（赤 色の流線)が見られ損失領域(A)を形成している一方, 後縁近傍では正圧面から負圧面への漏れ流れ (青色の流線) が存在し，コード方向に動翼の駆動モードに違いがあることが確認できる.

図 14(b)に示した HL 状態（ $\phi=1.2 ）$ では, 正圧面に発生する剥離渦が翼先端部まで巻き上がることはなく, 前 縁渦とスパン中央部で干渉寸ることで大きな損失領域(B)を Tip から約 50\%スパン位置に形成することがわかる. 前縁近傍での負圧面から正圧面への漏れ流れ（赤色の流線）はその規模が拡大し，後縁近傍での正圧面から負圧 面への漏れ流れ（青色の流線）と合流して損失領域(A)を形成する. また，八ブ面近傍の損失領域(C)は八ブ面上に 発達寸る境界層に起因する損失であることが黄色の流線からわかる.

このようにウインドミル駆動状態であっても, FW 状態（ $\phi=0.9 ）$ と HL 状態（ $\phi=1.2 ）$ では翼間流れの構造や 損失の発生機構が著しく異なることがわかる. 特に大きな損失が発生する領域(B)は, 縦渦と前縁渦の干渉によっ て生じており，その干涉位置によって下流側の損失形成メカニズムが大きく変化していることが予想されるが， その詳細な解明は次の段階の調査を待たなければならない. 

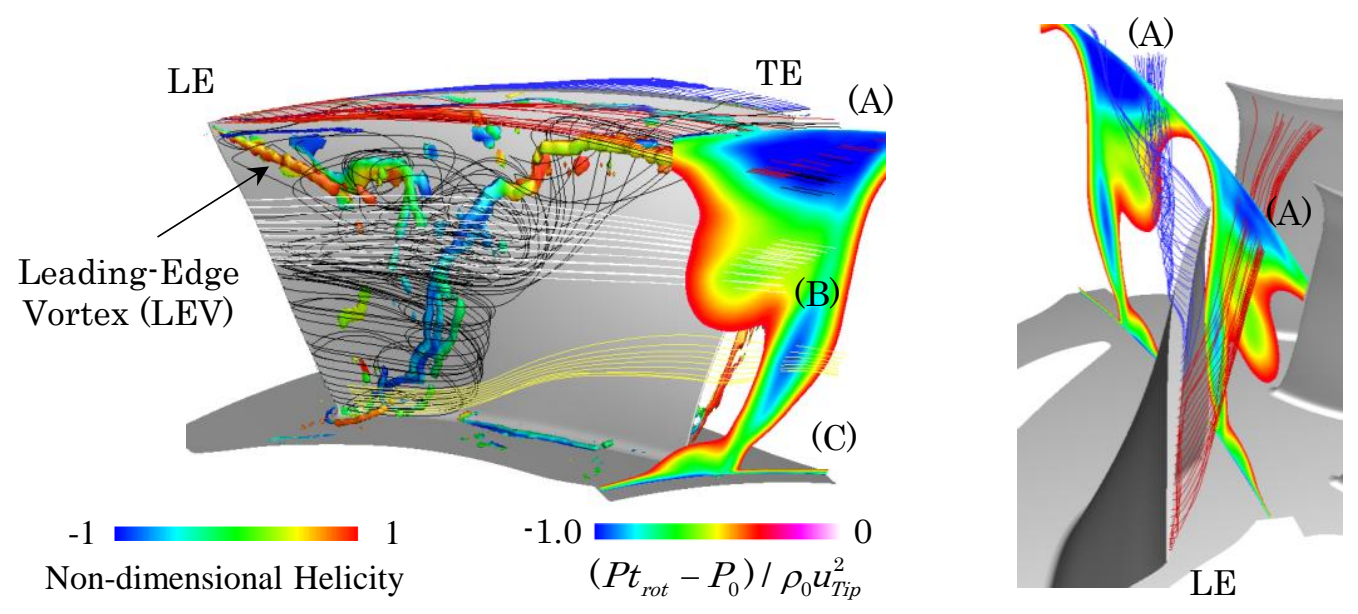

(a) Free-Windmilling $(\phi=0.9)$
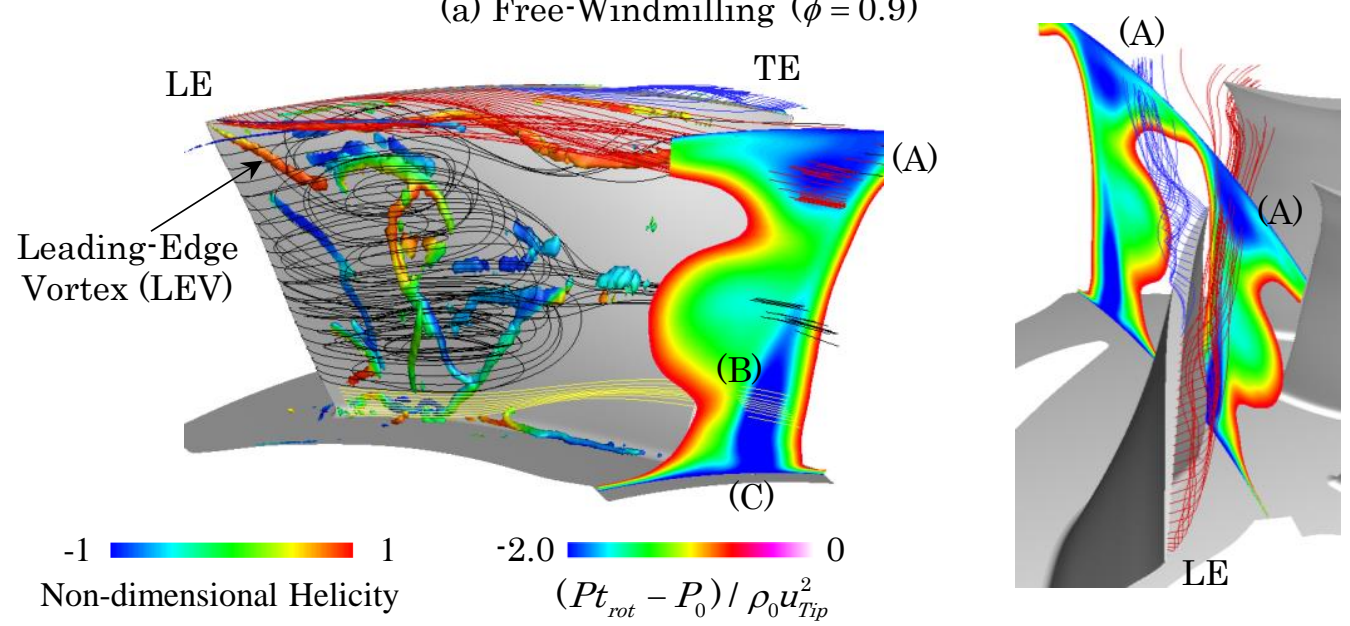

(b) Highly Loaded Windmilling ( $\phi=1.2)$

Fig. 14 Vortical structure on the pressure surface of rotor at free-windmilling and highly loaded windmilling conditions by DES. Vortices were visualized by critical point method and were colored by non-dimensional helicity. Rotor loss was mainly generated at three regions, which were the tip clearance (A), mid span region (B) where the longitudinal vortex interfere with the leading-edge vortex, and near the hub wall (C).

\section{2 動翼の仕事特性と駆動モード}

動翼の駆動モードを調査するために, 動翼正圧面と負圧面の静圧差から駆動モード $\Delta P^{*}$ を次式のように定義し, $\Delta P^{*}$ の翼面上の分布を図 15 に示した.

$$
\Delta P^{*}=P_{P S}^{*}-P_{S S}^{*}=\left(P_{P S}-P_{0}\right) / \rho_{0} u_{T i p}^{2}-\left(P_{S S}-P_{0}\right) / \rho_{0} u_{T i p}^{2}
$$

定義より, $\Delta P^{*}>0$ であれば圧縮機作動， $\Delta P^{*}<0$ であればタービン駆動となる. 図中の実線は正圧面と負圧面の静 圧差が丁度零となる $\Delta P^{*}=0$ を表している.

設計点 $(\phi=0.5)$ では, 動翼全体で $\Delta P^{*}>0$ となり圧縮機作動を示す. FW 状態（ $\phi=0.9 ）$ では負の入射角に起因 する剥離の影響により, 正圧面前縁側で静圧が低下し, 負圧面側では図 12 に示した主流部の加速に伴う静圧降下 がミッドコード付近に認められるため, 前縁側で $\Delta P^{*}<0$ となりタービン駆動, 後縁側では圧縮機作動となる. こ の結果より，両駆動モードの影響が結果として打ち消し合うことで図 6 に示した荷重係数が $\Psi=0$ となる. さら に, Hub 側より Tip 側でタービン駆動領域が約 $12 \%$ 程度拡大している. そのため, 図 7 に示した局所荷重係数 $\psi(r)$ では Tip 側でタービン駆動，Hub 側で圧縮機作動を示す. HL 状態（ $\phi=1.2 ）$ では全スパンにおいて前縁側のター 
ビン駆動領域が約 10\%拡大している．その結果，タービン駆動の影響が支配的となり動翼全体としてタービン駆 動形態となる.

既に述べた通り，FW 状態と HL 状態を比較すると，タービン駆動領域はコード方向にはたかだか $10 \%$ 程度し か拡大していないが, 図 11 に示したタービン駆動モードの強さを表す駆動力 $S_{T}$ が大きく変化して動翼の駆動モ ードを支配していることがわかる。

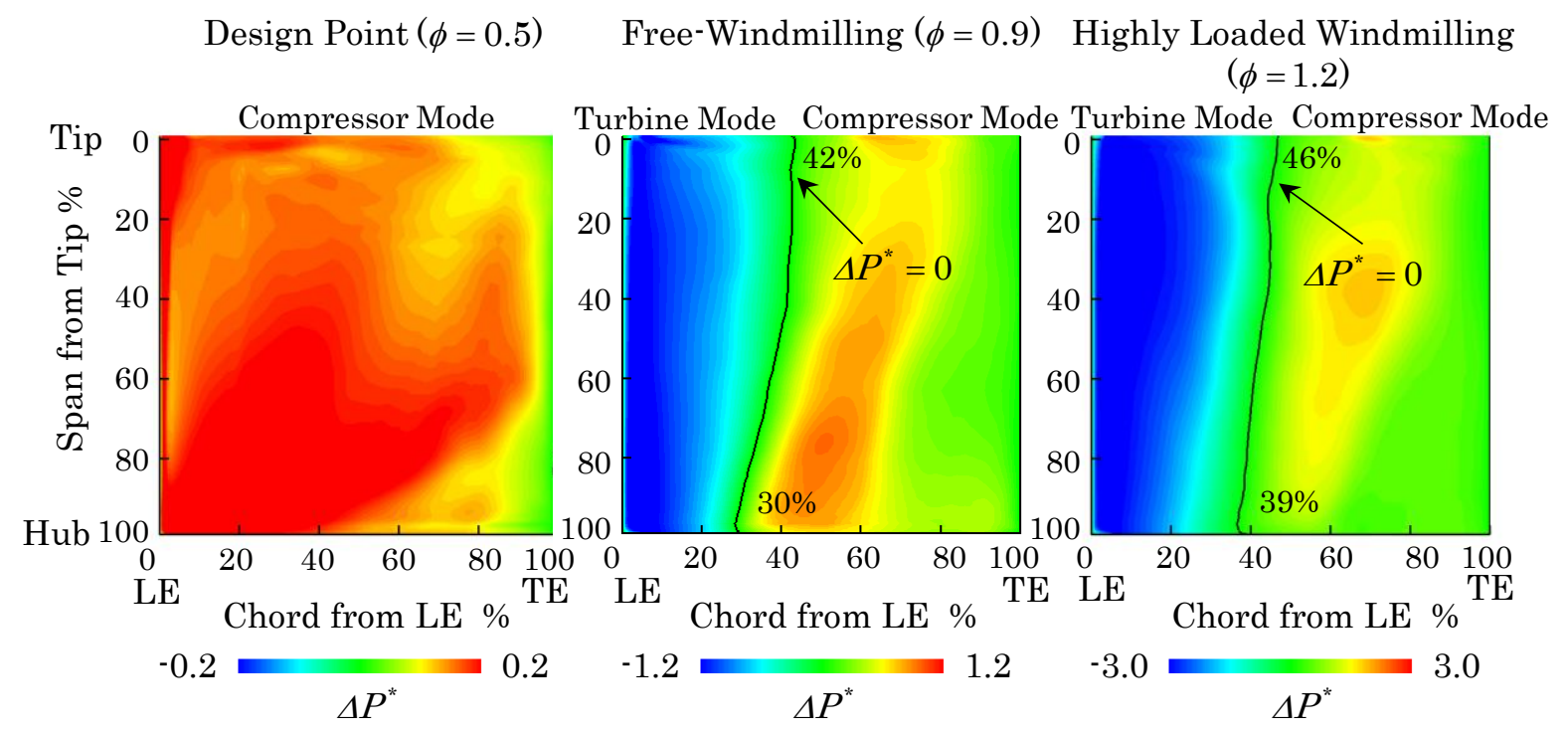

Fig. 15 Distribution of turbine and compressor operating modes on the rotor surface obtained by DES. In the case of freeand highly loaded windmilling conditions, size of turbine operating mode does not change so much, and more than half of the rotor surface works as compressor.

\section{7. 結 言}

円形風洞内に設置された単段軸流圧縮機試験装置と数值解析を用いて, 大流量非設計点でのウインドミル駆動 状態における動静翼特性と内部流れ場の調査を行った．特に，動翼と流体間でエネルギーの授受が相殺され荷重 係数が零となる Free-Windmilling 状態と, 荷重係数が負となって動翼がタービンとして駆動されて動力が発生す る Highly Loaded Windmilling 状態の動翼特性に着目し，以下に示すような知見を得た。

（1）設計点から流量係数を徐々に増大させると，動翼は Tip 側から徐々にウインドミル状態となる．FW 状態 では Hub 側で圧縮機作動，Tip 側でタービン駆動となり両駆動モードが共存する状態となるが，HL 状態 では全スパンにわたってタービン駆動となる.

（2）動翼表面上圧力の計測結果および数值解析結果より，動翼コード方向のウインドミル駆動領域は HL 状態 においても前縁からコード方向に 50\%以内に限定され，後縁近傍では HL 状態においても圧縮機作動状態 が継続されている．ウインドミル駆動領域の範囲は流量係数の影響を敏感には受けないが，動翼両面の圧 力差，つまりタービン駆動力の大きさが流量係数と共に著しく増大してウインドミル特性を支配する.

(3) 動翼は負の入射角に起因する正圧面側の剥離の影響を受け, 前縁側でタービン駆動, 後縁側では圧縮機作 動を示し，スパン方向のみならずコード方向にも駆動モードが分布する.

（4）ウインドミル状態の動翼列内で発生する主な損失の原因は，(1)翼先端隙間部での漏れ流れ，(2)負の入射角 に起因する正圧面側剥離渦と前緑渦との干渉，および(3)八ブ面近傍の境界層流れの 3 つに大別できる. 翼 端部では前縁近傍で負圧面側から正圧面側へ，後縁近くでは正圧面側から負圧面側へと漏れ流れが発生し， 大きな損失の原因となる．また，(2)に示した剥離渦と前縁渦との干渉によって発生する損失は，FW 状態 と HL 状態では全く発生機構が異なるが，その詳細なメカニズムの解明は翼列内非定常流れの詳細な調査 を待たなければならない。 


\section{文献}

Binder, N., Courty-Audren, S. K., Duplaa, S., Dufour, G. and Carbonneau, X., Theoretical analysis of the aerodynamics of lowspeed fans in free and load-controlled windmilling operation, Transactions of the ASME, Journal of Turbomachinery, Vol.137 (2015), 101001.

藤澤信道，原昇太郎，太田有，羽根付ディフューザを有する遠心圧縮機に発生する失速と前縁渦の関係，日本機 械学会論文集，Vol.81, No.829 (2015), DOI:10.1299/transjsme.15-00194.

Gill, A., von Backström, T. W. and Harms, T. M., The flow field within an axial flow compressor at extremely high flow coefficients, Proceedings of the ASME Turbo Expo, Glasgow, UK, GT2010-22894 (2010).

後藤尚志, 太田有，大田英輔，遠心圧縮機ディフューザに発生する前縁渦の非定常挙動と制御，日本機械学会論 文集 B 編，Vol.76，No.772 (2010)，pp.2039-2049.

Goto, T., Kato, D., Ohta, Y. and Outa, E., Unsteady flow structure in an axial compressor at windmill condition, Proceedings of the ASME Turbo Expo, Düsseldorf, Germany, GT2014-25609 (2014).

Greitzer, E. M., Tan, C. S. and Graf, M. B., Internal flow: concepts and applications, Cambridge University Press, Cambridge, UK (2004).

Gunn, E. J. and Hall, C. A., Loss and deviation in windmilling fans, Transactions of the ASME, Journal of Turbomachinery, Vol.138 (2016), 101002.

Hirayama, T., Ohta, Y., Goto, T. and Kato, D., Internal flow structure and rotor performance of an axial flow compressor at windmill conditions, Proceedings of the 13th ISAIF, Okinawa, Japan, ISAIF13-S-0031 (2017).

Imaeda, M., Kato, D., Ohta, Y., Totani, G. and Outa, E., Detailed flow field investigation of an axial flow compressor at windmill condition, Proceedings of the International Gas Turbine Conference, Osaka, Japan, IGTC2011-0030 (2011).

Menter, F. R., Two-equation eddy viscosity turbulence models for engineering applications, AIAA Journal, Vol.32 (1994), pp.269-289.

Ortolan, A., Courty-Audren, S., Binder, N., Carbonneau, X., Rosa, N. G. and Challas, F., Experimental and numerical flow analysis of low-speed fans at highly loaded windmilling conditions, Transactions of the ASME, Journal of Turbomachinery, Vol.139 (2017), 071009.

Ortolan, A., Courty-Audren, S. K., Lagha, M., Binder, N., Carbonneau, X. and Challas, F., Generic properties of flows in lowspeed axial fans operating at load-controlled windmill, Transactions of the ASME, Journal of Turbomachinery, Vol.140 (2018), 081002.

Prasad, D. and Load, W. K., Internal losses and flow behavior of a turbofan stage at windmill, Transactions of the ASME, Journal of Turbomachinery, Vol.132 (2010), 031007.

Roe, P. L., The use of the Riemann problem in finite difference schemes, Lecture Notes in Physics, Vol.141, Proceedings of the 7th Internal Conference on Numerical Methods in Fluid Dynamics, Springer Verlag (1980).

Sawada, K., A convenient visualization method for identifying vortex centers, Transactions of the Japan Society for Aeronautical and Space Sciences, Vol.38 (1995), pp.102-116.

Shima, E., A simple implicit scheme for structured/unstructured CFD, Proceedings of 29th Fluid Dynamics Conference (1997), pp.325-328.

Strelets, M., Detached eddy simulation of massively separated flows, AIAA Paper, 2001-0879 (2001).

van Leer, B., Towards the ultimate conservative difference scheme V: A second-order sequel to Godunov's method, Journal of Computational Physics, Vol.32 (1979), pp.101-136.

Walsh, P. P. and Fletcher, P., Gas turbine performance, Blackwell Science Ltd. (2004), pp.501-518.

\section{References}

Binder, N., Courty-Audren, S. K., Duplaa, S., Dufour, G. and Carbonneau, X., Theoretical analysis of the aerodynamics of lowspeed fans in free and load-controlled windmilling operation, Transactions of the ASME, Journal of Turbomachinery, Vol.137 (2015), 101001.

Fujisawa, N., Hara, S. and Ohta Y., Stall and leading-edge vortex in a centrifugal compressor with vaned diffuser, Transactions of the JSME (in Japanese), Vol.81, No.829 (2015), DOI:10.1299/transjsme.15-00194.

Gill, A., von Backström, T. W. and Harms, T. M., The flow field within an axial flow compressor at extremely high flow coefficients, Proceedings of the ASME Turbo Expo, Glasgow, UK, GT2010-22894 (2010). 
Goto, T., Ohta, Y. and Outa, E., Unsteady behavior and control of diffuser leading-edge vortex in a centrifugal compressor, Transactions of the Japan Society of Mechanical Engineers, Series B, Vol.76, No.772 (2010), pp.2039-2049 (in Japanese).

Goto, T., Kato, D., Ohta, Y. and Outa, E., Unsteady flow structure in an axial compressor at windmill condition, Proceedings of the ASME Turbo Expo, Düsseldorf, Germany, GT2014-25609 (2014).

Greitzer, E. M., Tan, C. S. and Graf, M. B., Internal flow: concepts and applications, Cambridge University Press, Cambridge, UK (2004).

Gunn, E. J. and Hall, C. A., Loss and deviation in windmilling fans, Transactions of the ASME, Journal of Turbomachinery, Vol.138 (2016), 101002.

Hirayama, T., Ohta, Y., Goto, T. and Kato, D., Internal flow structure and rotor performance of an axial flow compressor at windmill conditions, Proceedings of the 13th ISAIF, Okinawa, Japan, ISAIF13-S-0031 (2017).

Imaeda, M., Kato, D., Ohta, Y., Totani, G. and Outa, E., Detailed flow field investigation of an axial flow compressor at windmill condition, Proceedings of the International Gas Turbine Conference, Osaka, Japan, IGTC2011-0030 (2011).

Menter, F. R., Two-equation eddy viscosity turbulence models for engineering applications, AIAA Journal, Vol.32 (1994), pp.269-289.

Ortolan, A., Courty-Audren, S., Binder, N., Carbonneau, X., Rosa, N. G. and Challas, F., Experimental and numerical flow analysis of low-speed fans at highly loaded windmilling conditions, Transactions of the ASME, Journal of Turbomachinery, Vol.139 (2017), 071009.

Ortolan, A., Courty-Audren, S. K., Lagha, M., Binder, N., Carbonneau, X. and Challas, F., Generic properties of flows in lowspeed axial fans operating at load-controlled windmill, Transactions of the ASME, Journal of Turbomachinery, Vol.140 (2018), 081002.

Prasad, D. and Load, W. K., Internal losses and flow behavior of a turbofan stage at windmill, Transactions of the ASME, Journal of Turbomachinery, Vol.132 (2010), 031007.

Roe, P. L., The use of the Riemann problem in finite difference schemes, Lecture Notes in Physics, Vol.141, Proceedings of the 7th Internal Conference on Numerical Methods in Fluid Dynamics, Springer Verlag (1980).

Sawada, K., A convenient visualization method for identifying vortex centers, Transactions of the Japan Society for Aeronautical and Space Sciences, Vol.38 (1995), pp.102-116.

Shima, E., A simple implicit scheme for structured/unstructured CFD, Proceedings of 29th Fluid Dynamics Conference (1997), pp.325-328.

Strelets, M., Detached eddy simulation of massively separated flows, AIAA Paper, 2001-0879 (2001).

van Leer, B., Towards the ultimate conservative difference scheme V: A second-order sequel to Godunov's method, Journal of Computational Physics, Vol.32 (1979), pp.101-136.

Walsh, P. P. and Fletcher, P., Gas turbine performance, Blackwell Science Ltd. (2004), pp.501-518. 